\title{
PENGARUH MOTIVASI KERJA, KEPUASAN KERJA DAN KEADILAN ORGANISASI TERHADAP KOMITMEN KERJA PEGAWAI PADA DINAS PENDIDIKAN KABUPATEN KERINCI
}

\author{
EDWAR, ELFISWANDI \\ ${ }^{1}$ Fakultas Ekonomi dan Bisnis Universitas Putra Indonesia "YPTK" Padang \\ ${ }^{2}$ Fakultas Ekonomi dan Bisnis Universitas Putra Indonesia "YPTK" Padang \\ E-mail : \\ edwar.krc2008@gmail.com \\ elfiswandi@upiyptk.ac.id
}

\begin{abstract}
This study aims to determine the effect of independent variables on the dependent variable. The object of this research is the Kerinci Regency Education Office Staff. The number of samples in this study were 68 respondents. The analysis technique used is multiple linear regression. The results obtained by the partial test ( $t$ test) obtained: (a) There is a positive and significant influence of work motivation on work commitment. (b) There is a positive and significant influence of job satisfaction on work commitment. c) There is a positive and significant effect of organizational justice on work commitments. The results of the study simultaneously showed that work motivation, job satisfaction and organizational justice had a positive and significant effect on work commitment. work and organizational justice on the Work commitment dependent variable of 0,700 or $70.0 \%$. While the remaining $30.0 \%$ is influenced by other variables outside this study.
\end{abstract}

Keywords: Work Motivation, Job Satisfaction, Organizational Justice and Work Commitment

\begin{abstract}
ABSTRAK
Penelitian ini bertujuan untuk mengetahui pengaruh variabel independen terhadap variabel dependen. Objek penelitian ini adalah Pegawai Dinas Pendidikan Kabupaten Kerinci. Jumlah sampel dalam penelitian ini sebanyak 68 responden. Teknik analisis yang digunakan adalah regresi linear berganda. Hasil penelitian yang didapatkan berdasarkan Uji Parsial (Uji t) diperoleh: (a) Terdapat pengaruh positif dan signifikan motivasi kerja terhadap komitmen kerja. (b) Terdapat pengaruh positif dan signifikan kepuasan kerja terhadap komitmen kerja. c) Terdapat pengaruh positif dan signifikan keadilan organisasi terhadap komitmen kerja. Hasil penelitian secara simultan menunjukkan bahwa motivasi kerja, kepuasan kerja dan keadilan organisasi berpengaruh positif dan signifikan terhadap komitmen kerja.. Dan berdasarkan uji koefisien Determinasi $\left(\mathrm{R}^{2}\right)$ nilainya 0,700 atau $70,0 \%$ hal ini menunjukkan bahwa persentase sumbangan
\end{abstract}


variabel independen motivasi kerja, kepuasan kerja dan keadilan organisasi terhadap variabel dependen komitmen Kerja sebesar 0,700 atau 70,0\%. Sedangkan sisanya sebesar 30,0\% dipengaruhi oleh variabel lain di luar penelitian ini.

Kata kunci : Motivasi Kerja, Kepuasan Kerja, Keadilan Organisasi dan Komitmen kerja

\section{PENDAHULUAN}

Pegawai atau karyawan merupakan aset penting sebuah instansi atau perusahaan. Semua instansi atau perusahaan menjaga loyalitas dan kinerja pegawai, serta mengembangkan kreatifitas pegawai. Bagaimana mungkin pegawai dapat bekerja dengan baik jika kebutuhan dasarnya belum terpenuhi.

Disamping kompetensi pegawai, komitmen kerja juga menentukan baik tidaknya kinerja pegawai. Walaupun instansi tersebut memiliki pegawai yang sangat kompeten dalam pekerjaannya, tetapi jika pegawai tersebut tidak memiliki komitmen kerja yang tinggi maka kinerja yang dihasilkan juga tidak maksimal. Misalnya pegawai tersebut sering datang terlambat masuk kerja, sering tidak masuk tanpa alasan yang jelas, atau tidak berupaya memberikan kemampuan terbaiknya bagi instansi.

Menurut (Armstorng, 2016)mengatakan bahwa komitmen kerja adalah tentang mengenal pasti tujuan dan nilai organisasi, keinginanmenjadi milik organisasi dan kesanggupan untuk berusaha menjadi milik organisasi. Baron dan Armstrong juga menjelaskan bahwa komitmen dapat memastikan organisasi itu dilihat sebagai "tempat yang hebat untuk bekerja", lalu menjadikannya "pemimpin pilihan". Hal serupa juga diungkapkan (Steers, 2014) yang mengatakan bahwa komitmen kerja mencangkup kesamaan nilai dan tujuan antara individu dan instansi, keterlibatan anggota dan juga loyalitas dari anggota.

Sumber daya manusia merupakan salah satu faktor penting bagi organisasi dalam mewujudkan visi dan misi dari organisasi yang diciptakan agar tercipta organisasi yang diinginkan. Dimana sumber daya manusia yang merupakan penggerak dari sebuah organisasi yang akan menjalankan organisasi tersebut dan sumber daya manusia merupakan salah satu unsur yang sangat penting dalam suatu organisasi. Untuk itu sangat diperlukan pengelolaan sumber daya manusia yang efisien dan efektif di dalam sebuah organisasi, agar tercipta organisasi yang berkualitas. Dengan pengelolaan sumber daya manusia yang baik akan menunjang dari cara kerja organisasi tersebut melalui cara kerja pegawai. Karena kerja pegawai yang efisien dan efektif yang sesuai dengan visi dan misi dari oganisasi, maka akan terwujud tujuan yang diinginkan organisasi.

Salah satu hal penting yang harus diperhatikan adalah motivasi. Motivasi merupakan suatu proses yang membangkitkan, mengarahkan dan menjaga atau memelihara perilaku manusia agar terarah pada tujuan. Untuk lebih meningkatkan performance dan sikap positif, sebaiknya menggunakan dan berpusat pada faktor motivasi. Kepuasan pegawai menjadi penting karena merupakan salah satu kunci 
pendorong moral dan disiplin serta kinerja pegawai yang akan berpengaruh terhadap kualitas pelayanan dalam upaya mewujudkan sasaran instansi.

Untuk mewujudkan tujuan dari sebuah organisasi, organisasi membutuhkan sumber daya manusia yang berkomitmen dalam bekerja. Hal ini sejalan dengan pendapat (Mayer, 2014) juga menyatakan bahwa pegawai yang memiliki komitmen organisasi akan bekerja dengan penuh dedikasi karena pegawai yang memiliki komitmen menganggap bahwa hal yang penting yang harus dicapai adalah pencapaian tugas dalam organisasi. Pegawai yang memiliki komitmen organisasi juga memiliki pandangan yang positif dan akan melakukan yang terbaik untuk kepentingan organisasi. Hal ini membuat pegawai memiliki keinginan untuk memberikan tenaga dan tanggung jawab yang lebih menyokong kesejahteraan dan keberhasilan organisasi tempatnya bekerja.

(Melayu, 2017)menjelaskan, bahwa Motivasi Kerja secara umum dapat diidentifikasi sebagai serangkaian kekuatan penggerak yang muncul dari dalam dan luar diri masing-masing individu. Kedua kekuatan itu menimbulkan minat kerja dan berhubungan dengan tingkah laku dan menentukan arah, intensitas, dan durasi dari tingkah laku atau kebiasaan individual. (Mangkunegara, 2016) Motivasi merupakan kondisi atau energi yang menggerakkan diri pegawai yang terarah atau setuju untuk mencapai tujuan organisasi instansi

Pegawai yang memiliki komitmen organisasi akan memberikan usaha yang maksimal secara sukarela untuk kemajuan organisasi. Salah satu faktor yang mempengaruhi komitmen organisasi adalah kepuasan kerja. Pegawai yang merasa puas pada tugas dan lingkungannya akan merasakan adanya persamaan dengan organisasi dan terlibat pada aktivitas instansi. Kepuasan kerja nampak dalam sikap positif pegawai terhadap pekerjaannya dan segala sesuatu yang dihadapi dilingkungan kerjanya.

Banyak dampak yang akan timbul jika seseorang tersebut merasa puas akan tempatnya bekerja. Salah satu dampaknya adalah pada komitmen kerja orang tersebut. Kepuasan kerja merupakan salah satu faktor yang sangat penting untuk mendapatkan hasil kerja yang optimal. Ketika seorang merasakan kepuasan dalam bekerja tentunya ia akan berupaya semaksimal mungkin dengan segenap kemampuan yang dimilikinya untuk menyelesaikan tugas pekerjaannya. Ketidakpuasan dalam bekerja pegawai Dinas Pendidikan Kabupaten Kerinci terlihat dari saat bekerja yang ada hanya bermain telepon genggam, terlihat seringnya pegawai yang tidak berada di tempat saat bekerja.

\subsection{Objek Penelitian}

\section{METODOLOGI PENELITIAN}

Objek penelitian merupakan sasaran untuk mendapatkan suatu data, dalam penelitian ini yang menjadi objek penelitian yaitu dilakukan pada pegawai Dinas Pendidikan Kabupaten Kerinci dengan alamat Komplek Perkantoran Bukit Tengah Kecamatan Siulak Kabupaten Kerinci Provinsi Jambi.

\subsection{Variabel Operasional}

Pada penelitian ini penulis menggunakan dua variabel yaitu:

- $\quad$ Variabel independen (bebas) 
Variabel bebas adalah merupakan variabel yang mempengaruhi atau yang menjadi sebab perubahannya atau timbulnya variabel dependen atau terikat. Dalam penelitian ini yang menjadi variabel bebas (independent variable) adalah Motivasi Kerja $\left(\mathrm{X}_{1}\right)$, Kepuasan Kerja $\left(\mathrm{X}_{2}\right)$ dan Keadilan Organisasi $\left(\mathrm{X}_{3}\right)$.

- Variabel dependen (terikat)

Variabel terikat merupakan variabel yang dipengaruhi atau yang menjadi akibat, karena adanya variabel bebas. Dalam penelitian ini yang menjadi variabel terikat (dependent variable) adalah Komitmen Kerja (Y).

\subsection{Populasi dan Sampel}

Menurut (Sugiyono, 2014) Populasi adalah wilayah generalisasi yang terdiri atas objek atau subjek yang mempunyai kualitas dan karakteristik tertentu yang ditetapkan oleh peneliti untuk dipelajari dan kemudian ditarik kesimpulannya. Populasi juga dapat diartikan sebagai himpunan atau kumpulan dari sebuah objek penelitian yang mana perkumpulan dari karyawan tersebut bisa dikategorikan sebagai populasi. Dalam penelitian ini yang menjadi populasi adalah seluruh pegawai Dinas Pendidikan Kabupaten Kerinci yang berjumlah 98 orang.

Menurut (Sugiyono, 2014) Sampel adalah bagian dari jumlah dan karakteristik yang dimiliki oleh populasi tersebut. Sampel merupakan bagian terkecil dari populasi yang dijadikan sebagi sumber data bagi peneliti dalam menyelesaikan penelitiannya, karena sampel dapat mawakili populasi atau perusahaan yang akan diteliti. Sampel yang digunakan dalam penelitian ini adalah seluruh pegawai Dinas Pendidikan Kabupaten Kerinci.

Pemilihan sampel untuk penelitian ini dilakukan dengan probability sampling yaitu populasi yang dijadikan sampel adalah populasi yang memenuhi kriteria tertentu dengan tujuan agar sampel yang diambil bisa lebih representatif dengan kriteria yang telah ditentukan. Dalam penelitian ini teknik pengambilan sampel dengan menggunakan sampel jenuh. Dimana untuk menentukan besar sampel digunakan seluruh populasi yang ada.

Berdasarkan uraian di atas maka sampel pada penelitian ini berjumlah 68 didapat dari 98 populasi dikurangi dengan 30 responden digunakan untuk uji instrument dan sisanya 68 responden digunakan untuk sampel penelitian ini.

\subsection{Analisis Regresi Linier Berganda}

Alat analisis data yang digunakan dalam penelitian ini adalah analisis regresi berganda untuk membuktikan motivasi kerja, kepuasan kerja dan keadilan organisasi terhadap komitmen kerja pegawai pada Dinas Pendidikan Kabupaten Kerinci. Menurut (Anwar, 2014)secara umum regresi berganda dapat dirumuskan sebagai berikut :

$$
\mathbf{Y}=\mathbf{a}+\mathbf{b}_{1} \mathbf{X}_{1}+\mathbf{b}_{2} \mathbf{X}_{2}+\mathbf{b}_{3} \mathbf{X}_{3}+e
$$

Keterangan :

$$
\begin{array}{ll}
\mathrm{Y} & =\text { Komitmen kerja } \\
\mathrm{a} & =\text { Konstanta } \\
\mathrm{b} & =\text { Koefisien regresi } \\
\mathrm{X}_{1} & =\text { Motivasi kerja } \\
\mathrm{X}_{2} & =\text { Kepuasan kerja } \\
\mathrm{X}_{3} & =\text { Keadilan organisasi }
\end{array}
$$




\section{Uji Parsial (Uji-t)}

$$
\text { e } \quad=\text { error }
$$

Uji t dilakukan untuk mengatahui tingkat signifikan pengaruh variabel bebas terhadap variabel terikat secara parsial. Dalam hal ini untuk menguji pengaruh motivasi kerja, kepuasan kerja dan keadilan organisasi terhadap komitmen kerja.

\section{Uji Simultan (Uji-F)}

Uji statistik $F$ digunakan untuk menguji seluruh variabel independen motivasi kerja, kepuasan kerja dan keadilan organisasi yang diteliti mempunyai pengaruh secara bersama-sama terhadap variabel dependen komitmen organisasi dilakukan dengan membandingkan F-hitung dengan f-tabel.

\section{Uji Koefisien Determinasi ( $\left.\mathbf{R}-S q u a r e / \mathbf{R}^{2}\right)$}

Koefisien determinasi berganda $\left(\mathrm{R}^{2}\right)$ atau $\mathrm{R}$ squared berarti secara bersama-sama menyatakan besar kecilnya sumbangan variabel bebas terhadap variabel terikat. $\mathrm{R}$ squared berkisar pada angka 0 sampai 1, dengan catatan semakin kecil angka $\mathrm{R}$ squared, semakin lemah pula hubungan kedua atau lebih varibel tersebut.

\section{III.HASIL DAN PEMBAHASAN}

Berdasarkan sampel yang telah ditentukan diatas maka diperoleh responden sebanyak 95 orang. Dimana 95 responden tersebut peneliti ambil dari keseluruhan populasi yang ada pada Dinas Pendidikan Kabupaten Kerinci. Data yang disebarkan sebanyak 95 kuesioner dan berhasil dikumpulkan kembali kemudian diolah semuanya.

\section{Uji Normalitas}

Penilaian normalitas dilakukan dengan memperhatikan nilai signifikan, jika nilai signifikan lebih besar (>) 0,05 maka data dikatakan normal, sebaliknya jika nilai signifikan kecil dari (<) 0,05 maka data dikatakan tidak normal. Pengujian normalitas residual dapat dilihat dari grafik normal P-P Plot. Apabila setiap lingkaran data residual berada disekitar garis lurus melintang, maka dikatakan bahwa residual mengikuti fungsi distribusi normal. Berdasarkan uji normalitas dengan menggunakan uji One-Sample Kolmogorov-Smirnov, terlihat bahwa nilai Kolmogorov-Smirnov untuk variabel residual sebesar 0,658 dan signifikan pada 0,779 di atas 0,05 . Hal ini mengindikasikan bahwa data residual terdistribusi normal yang memperkuat hasil pengujian dengan menggunakan grafik normal P-P Plot.

Tabel 4.1 Uji Normalitas

\begin{tabular}{|c|c|c|}
\hline & & $\begin{array}{c}\text { Unstandardi } \\
\text { zed } \\
\text { Residual } \\
\end{array}$ \\
\hline $\mathrm{N}$ & & 68 \\
\hline Normal & Mean & 0.0000000 \\
\hline $\begin{array}{l}\text { Parameters } \\
\text { b }\end{array}$ & $\begin{array}{l}\text { Std. } \\
\text { Deviation }\end{array}$ & 2.23828749 \\
\hline Most & Absolute & 0.080 \\
\hline
\end{tabular}




\begin{tabular}{ll} 
Extreme $\quad$ Positive & 0.080 \\
Differences Negative & -0.059 \\
Test Statistic & 0.658 \\
Asymp. Sig. (2-tailed) & 0.779 \\
\hline
\end{tabular}

Sumber : Data diolah peneliti, 2020

\section{Uji Multikolinearitas}

Penilaian multikolinearitas dilakukan dengan membandingkan nilai VIF, jika nilai VIF > 5 atau 10 dan nilai toleransi mendekati 1 (satu) maka tidak terjadi multikoliniearitas. Namun jika sebaliknya, jika nilai VIF $>5$ atau 10 dan nilai toleransi menjauhi 1 (satu) maka terjadi multikolinearitas. Hasil uji multikolinearitas dapat dilihat pada tabel berikut :

Tabel 4.2 Hasil Uji Multikolinearitas

Sumber : Data diolah peneliti, 2020

\begin{tabular}{|c|c|c|c|}
\hline & \multicolumn{2}{|c|}{$\begin{array}{l}\text { Collinearity } \\
\text { Statistics } \\
\text { Toleran }\end{array}$} \\
\hline & Model & ce & VIF \\
\hline \multirow[t]{4}{*}{1} & (Constant) & & \\
\hline & X1_MOKER & 0.654 & 1.530 \\
\hline & $\begin{array}{l}\text { X2_KEPKE } \\
\text { R }\end{array}$ & 0.454 & 2.203 \\
\hline & X3 KEOR & 0.594 & 1.683 \\
\hline
\end{tabular}

Dari tabel di atas dapat diketahui bahwa variabel motivasi kerja $\left(\mathrm{X}_{1}\right)$ memiliki nilai tolerance 0,654 mendekati 1 (satu) dan nilai VIF 1,530 lebih kecil dari 5 atau 10 maka dinyatakan data tidak terjadi multikoliniearitas. Variabel kepuasan kerja $\left(\mathrm{X}_{2}\right)$ memiliki nilai tolerance 0,454 mendekati 1 (satu) dan nilai VIF 2,203 lebih kecil dari 5 atau 10 maka dinyatakan data tidak terjadi multikoliniearitas. Variabel keadilan organisasi $\left(\mathrm{X}_{3}\right)$ memiliki nilai tolerance 0,594 mendekati 1 (satu) dan nilai VIF 1,683 lebih kecil dari 5 atau 10 maka dinyatakan data tidak terjadi multikoliniearitas.

\section{Uji Heteroskedastisitas}

Penilaian heteroskedastisitas dapat diperhatikan pada tabel coefficients dengan memperhatikan nilai signifikan yang dihasilkan. Jika nilai signifikan > 0,05 maka tidak terjadi heteroskedastisitas. Sebaliknya, jika nilai signifikannya < dari 0,05 maka terjadi heteroskedasititas. Hasil uji heteroskedasititas dapat dilihat pada gambar berikut :

Gambar 4.3 Hasil Uji Heteroskedastisitas 


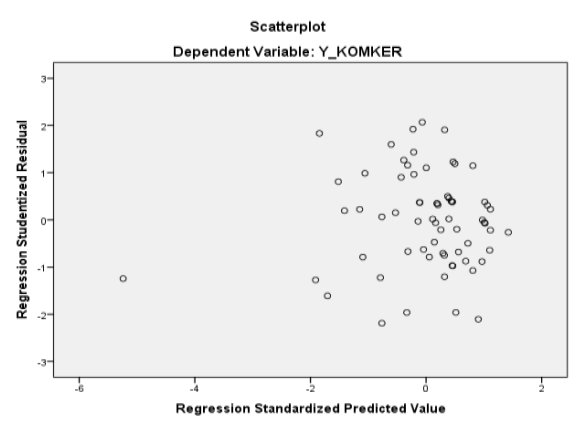

Sumber : Data diolah peneliti, 2020

Dari grafik diatas dapat diketahui bahwa tidak terjadi heteroskedastisitas pada model regresi sebab tidak ada pola yang jelas serta titik-titik menyebar diatas dan dibawah angka 0 pada sumbu Y. Sehingga dapat dikatakan uji heteroskedastisitas terpenuhi.

\section{Analisis Regresi Linier Berganda}

Untuk mengetahui pengaruh antara variabel motivasi kerja, kepuasan kerja dan keadilan organisasi terhadap komitmen kerja maka digunakan analisis regrsi linier berganda, dimana variabel bebasnya adalah motivasi kerja (X1), kepuasan kerja (X2), keadilan organisasi (X3) serta variabel terikatnya adalah komitmen kerja (Y). berikut hasil uji regresi yang dilakukan. Adapun bentuk regresinya adalah sebagai berikut:

Tabel 4.3 Hasil Regresi Linier Berganda

\begin{tabular}{|l|c|c|c|c|}
\hline \multirow{2}{*}{ Model } & \multicolumn{2}{|c|}{$\begin{array}{c}\text { Unstandardiz } \\
\text { ed } \\
\text { Coefficients }\end{array}$} & \multirow{2}{*}{ Sig. } & \\
\cline { 2 - 4 } & B & $\begin{array}{c}\text { Std. } \\
\text { Error }\end{array}$ & & \\
\hline (Constant) & 2.355 & 3.519 & 0.669 & 0.506 \\
X1_MOK & 0.184 & 0.085 & 2.161 & 0.034 \\
ER & & & & \\
X2_KEPK & 0.327 & 0.102 & 3.199 & 0.002 \\
ER & & & & \\
X3_KEOR & 0.444 & 0.078 & 5.718 & 0.000 \\
\hline
\end{tabular}

Sumber : Data diolah peneliti, 2020

Berdasarkan perhitungan diperoleh nilai koefisien regresi motivasi kerja $\left(X_{1}\right)$ sebesar 0,184 , nilai koefisien regresi kepuasan kerja $\left(X_{2}\right)$ sebesar 0,327, nilai koefisien regresi keadilan organisasi $\left(\mathrm{X}_{3}\right)$ sebesar 0,444. Berdasarkan angka tersebut maka dapat disusun persamaan garis regresi sebagai berikut :

$$
Y=2,355+0,184 X_{1}+0,327 X_{2}+0,444 X_{3}+e
$$

\section{Uji Parsial (Uji-t)}

Uji t dimaksudkan untuk mengetahui seberapa besar pengaruh satu variabel independen (motivasi kerja, kepuasan kerja dan keadilan organisasi) 
secara individual dalam menerangkan variabel dependen (komitmen kerja). Hasil uji t pada penelitian ini dapat dilihat pada tabel 4.3 di atas :

a) Variabel Motivasi Kerja $\left(\mathrm{X}_{1}\right)$

$\mathrm{H}_{0}$ : Motivasi Kerja tidak berpengaruh positif dan signifikan terhadap Komitmen Kerja.

$\mathrm{H}_{1}$ : Motivasi Kerja berpengaruh positif dan signifikan terhadap Komitmen Kerja.

Hasil pengujian dengan SPSS diperoleh untuk variable Motivasi Kerjaterlihat t-hitung 2,161 > t-tabel 1,9977 dan nilai signifikan 0,034< 0,05. Yang berarti $\mathrm{H}_{0}$ ditolak $\mathrm{H}_{1}$ diterima. Dengan demikian hipotesis pertama diterima.

b) Variabel Kepuasan Kerja $\left(\mathrm{X}_{2}\right)$

$\mathrm{H}_{0}$ : Kepuasan Kerja tidak berpengaruh positif dan signifikan terhadap Komimen Kerja.

$\mathrm{H}_{2}$ : Kepuasan Kerja berpengaruh positif dan signifikan terhadap Komitmen Kerja.

Hasil pengujian dengan SPSS diperoleh untuk variable Kepuasan Kerja diatas terlihat t-hitung 3,199 > t-tabel 1,9977dan nilai signifikan $0,002<0,05$. Yang berarti $\mathrm{H}_{0}$ ditolak $\mathrm{H}_{2}$ diterima. Dengan demikian hipotesis kedua diterima.

c) Variabel Keadilan Organisasi $\left(\mathrm{X}_{3}\right)$

$\mathrm{H}_{0}$ : Keadilan Organisasi tidak berpengaruh positif dan signifikan terhadap Komitmen Kerja.

$\mathrm{H}_{3}$ : Keadilan Organisasi berpengaruh positif dan signifikan terhadap Komitmen Kerja.

Hasil pengujian dengan SPSS diperoleh untuk variable Keadilan Organisasi diatas terlihat t-hitung 5,718 > t-tabel 1,9977 dan nilai signifikan 0,000 $<0,05$. Yang berarti $\mathrm{H}_{0}$ ditolak $\mathrm{H}_{3}$ diterima. Dengan demikian hipotesis ketiga diterima.

\section{Uji Simultan (Uji-F)}

Untuk mendapatkan bukti empiris ada atau tidaknya pengaruh nyata antara variabel yang terdiri dari motivasi kerja, kepuasan kerja dan keadilan organisasi secara bersama-sama terhadap komitmen kerja, maka dilakukan F-test. Berdasarkan hasil pengujian diperoleh ringkasan hasil seperti yang terlihat pada tabel di bawah ini :

Tabel 4.4 Hasil Uji Simultan

\begin{tabular}{|c|c|c|c|c|c|}
\hline & $\begin{array}{l}\text { Sum of } \\
\text { Square }\end{array}$ & & Mean & & \\
\hline Model & $\mathrm{s}$ & $\mathrm{df}$ & Square & $\mathrm{F}$ & Sig. \\
\hline 1 Regressio & 837.09 & 3 & 279.03 & 53.20 & 0.00 \\
\hline $\mathrm{n}$ & 9 & & 3 & 2 & $0^{\mathrm{b}}$ \\
\hline Residual & $\begin{array}{r}335.66 \\
5\end{array}$ & 64 & 5.245 & & \\
\hline
\end{tabular}


Total $\quad 1172.7 \quad 67$

65

Sumber : Data diolah peneliti, 2020

Dari tabel 4.4 di atas, diketahui bahwa Pengujian pengaruh variabel bebas secara bersama-sama terhadap variabel terikat dilakukan dengan menggunakan uji F. hasil pengujian statistik menunjukan nilai $\mathrm{F}$ hitung 53,202 > F tabel 2,75 dengan signifikan sebesar 0,000 $<0,05$. Hal ini berarti bahwa $\mathrm{H}_{0}$ ditolak $\mathrm{H}_{4}$ diterima, dengan demikian secara bersama-sama motivasi kerja, kepuasan kerja dan keadilan organisasi mempunyai pengaruh yang signifikan terhadap komitmen kerja.

\section{Uji Koefisien Determinasi (R-Square)}

Analisis determinasi dalam regresi linier berganda digunakan untuk mengetahui persentase sumbangan pengaruh variabel independen terdiri dari motivasi kerja $\left(\mathrm{X}_{1}\right)$, kepuasan kerja $\left(\mathrm{X}_{2}\right)$, keadilan organisasi $\left(\mathrm{X}_{3}\right)$ terhadap komitmen kerja (Y). Berdasarkan hasil pengujian diperoleh ringkasan hasil seperti yang terlihat pada tabel di bawah ini :

\section{Tabel 4.5 Hasil Uji Koefisien Determinasi}

\begin{tabular}{|c|c|c|c|c|}
\hline $\begin{array}{l}\text { Mod } \\
\text { el }\end{array}$ & $\mathrm{R}$ & $\begin{array}{c}\mathrm{R} \\
\text { Square }\end{array}$ & $\begin{array}{c}\text { Adjuste } \\
\text { d R } \\
\text { Square }\end{array}$ & $\begin{array}{c}\text { Durbi } \\
\text { n- } \\
\text { Wats } \\
\text { on }\end{array}$ \\
\hline 1 & $\begin{array}{r}0.84 \\
5^{\mathrm{a}}\end{array}$ & 0.714 & 0.700 & 1.630 \\
\hline
\end{tabular}

Sumber : Data diolah peneliti, 2020

Dari tabel di atas diketahui angka Adjust $R$ square sebesar 0,700 hal ini menunjukan bahwa sumbangan variabel motivasi kerja, kepuasan kerja dan keadilan organisasi terhadap komitmen kerja 0,700 atau $70 \%$ sedangkan sisanya sebesar 30\% dipengaruhi variabel lain diluar penelitian ini.

\section{Pembahasan}

\section{Pengaruh Motivasi Kerja terhadap Komitmen Kerja}

Dari hasil pengujian penelitian menyatakan bahwa terdapat pengaruh positif dan signifikan antara motivasi kerjadengan komitmen kerja pada Dinas Pendidikan Kabupaten Kerinci. Terbukti kebenarannya, dari t-hitung 2,161 dan t-tabel 1,9977 dimana t-hitung lebih besar dari t-tabel $(2,161>1,9977)$ atau tingkat signifikan lebih kecil dari alpha $(0,034<0,05)$.

Hasil penelitian tersebut dinyatakan sejalan dengan penelitian yang dilakukan oleh Suwardi (2014) dan Hidayat (2018) menyatakan bahwa motivasi kerja berpengaruh positif dan signifikan terhadap komitmen kerja Pegawai.

\section{Pengaruh Kepuasan Kerja terhadap Komitmen Kerja}

Dari hasil pengujian penelitian menyatakan bahwa terdapat pengaruh positif dan signifikan antara kepuasan kerja dengan komitmen kerja pada Dinas Pendidikan Kabupaten Kerinci. Terbukti kebenarannya, dari t-hitung 3,199 dan t-tabel 1,9977 dimana t-hitung lebih besar dari t-tabel $(3,199>1,9977)$ atau tingkat signifikan lebih kecil dari alpha $(0,002<0,05)$. 
Penelitian yang dilakukan oleh Bambang Supriyanto (2015) dan I Made Angga Saputra (2018) menyatakan bahwa kepuasan kerja berpengaruh positif signifikan terhadap komitmen kerja pegawai.

\section{Pengaruh Keadilan Organisasi terhadap Komitmen Kerja}

Dari hasil pengujian penelitian menyatakan bahwa terdapat pengaruh positif dan signifikan antarakeadilan organisasi dengan komitmen kerja pada Dinas Pendidikan Kabupaten Kerinci. Terbukti kebenarannya, dari t-hitung 5,718 dan t-tabel 1,9977 dimana t-hitung lebih besar dari t-tabel $(5,718>1,9977)$ atau tingkat signifikan lebih kecil dari alpha $(0,000<0,05)$.

Selanjutnya penelitian yang dilakukan oleh Ni Putu Linda Pratiwi (2019) dan Farly C. M. Teneh (2015) menyatakan bahwa keadilan organisasi terdapat pengaruh positif dan signifikan terhadap komitmen kerja pegawai.

\section{Pengaruh Motivasi Kerja, Kepuasan Kerja dan Keadilan Organisasi terhadap Komitmen Kerja}

Dari hasil pengujian penelitian menyatakan bahwa secara bersama-sama terdapat pengaruh signifikan antara motivasi kerja, kepuasan kerja dan keadilan organisasi dengan komitmen kerja pegawai pada Dinas Pendidikan Kabupaten Kerinci. Terbukti kebenarannya, dimana nilai $F_{\text {hitung }}$ dengan $F_{\text {tabel }}$ karena nilai $F_{\text {hitung }}$ lebih besar dari $F_{\text {tabel }}(53,202>2,75)$, dengan tingkat signifikan 0,000 lebih kecil dari 0,05 .

Hasil penelitian tersebut sejalan dengan penelitian Bambang Supriyanto (2015) bahwa motivasi kerja, kepuasan kerja dan keadilan organisasisecara bersama-sama berpengaruh positif dan signifikan terhadap komitmen kerja.

\section{KESIMPULAN}

Hasil penelitian ini menunjukkan bahwa motivasi kerja berpengaruh dan signifikan terhadap komitmen kerja, kepuasan kerja berpengaruh dan signifikan terhadap komitmen kerja, keadilan organisasi berpengaruh dan signifikan terhadap komitmen kerja, motivasi kerja, kepuasan kerja, keadilan organisasi secara bersama-sama berpengaruh dan signifikan terhadap komitmen kerja pegawai pada Dinas Pendidikan Kabupaten Kerinci.

\section{UCAPAN TERIMAKASIH}

Terima kasih kepada Universitas Putra Indonesia "YPTK" Padang yang telah memberikan kesempatan penulis untuk menyelesaiakan jurnal ini dan LPPM STIA Nusantara Sakti Sungai Penuh yang telah memberi kesempatan untuk publish jurnal di OJS Jurnal Administrasi Nusantara (JAN). Sertasemua pihak yang tidak bisa disebutkan satu persatu dalam jurnal ini.

\section{VI.DAFTAR PUSTAKA}

Akbar, D. M. (2017). Pengaruh Motivasi Kerja Dan Kepuasan Kerja Terhadap Komitmen Organisasi Pegawai Rumah Sakit Pku Muhammadiyah Bantul . Procedding health Architecture .

Anwar, S. (2014). Metodologi Penelitian Bisnis. Jakarta: Salemba Empat. 
Armstorng, B. d. (2016). Performance Management-The New Realities. London: Institute of Personnel and Development.

Bangun, W. (2012). Manajemen Sumber Daya Manusia. Jakarta: Erlangga.

Candika, J. (2018). Pengaruh Keadilan Organisasional Terhadap Komitmen Organisasional Melalui Variabel Intervening Kepuasan Kerja Pada Karyawan Pt. Lembah Karet Padang . Jurnal Banefita .

Darmawan. (2013). Prinsip-Prinsip Perilaku Organisasi. Surabaya: PT. Temprina Media Grafika.

Edison, E. (2015). Manajemen Sumber Daya Manusia. Bandung: Alfabeta.

Edy, T. d. (2013). Pengaruh Motivasi Kerja Dan Kepuasan Kerja Terhadap Komitmen Organisasional Karyawan Pt. Dai Knife Di Surabaya. AGORA Vol. 1, No. 3 .

George, T. R. (2016). Manajemen Sumber Daya Manusia. Jakarta: CV. Haji Masagung.

Indriani, L. P. (2016). Pengaruh Keadilan Organisasional Terhadap Kepuasan Kerja Dan Komitmen Organisasional Pada Karyawan . Jurnal Manajemen Unud.

Kadarisman. (2012). Manajemen Pengembangan Sumber Daya Manusia. Jakarta: Raja Grafindo Persada.

Kaswan. (2017). Psikologi Industri dan Organisasi. Bandung: Alfabeta.

Kreitner, R. d. (2014). Perilaku Organisasi. Edisi 9. Buku 1. . Jakarta: Salemba Empat.

Kusumaputri, E. S. (2015). Komitmen pada Perubahan Organisasi: Perubahan Organisasi dalam Perspektif Islam dan Psikologi. Yogyakarta: Deepublish.

Luthans, F. (2014). Perilaku Organisasi, (Alih Bahasa V.A Yuwono, dkk),Edisi Bahasa Indonesia. Yogyakarta: PT. Raja Grafindo.

Mangkunegara, A. P. (2016). ManajemenSumberDayaManusiaPerusahaan. Bandung: PT.RemajaRosdakarya.

Mar'at. (2013). Sikap Manusia : Perubahan serta Pengukurannya. Bandung: Ghalia Indonesia.

Mathis, R. L. (2012). Manajemen Sumber Daya Manusia. Buku 1, Alih Bahasa: Jimmy Sadeli dan Bayu. Prawira Hie. Jakarta: Salemba Empat.I

Mayer, A. d. (2014). The Measurement and Antecedents of Affective, Contintinuance and NormativeCommitment to Organitazion. Jakarta: PT Elex Media Komputindo.

Melayu, H. (2017). Manajemen Sumber Daya Manusia. Jakarta: Bumi Aksara.

Mowday. (2014). Employee-OrganizationLinkages. Texas: South-Western Cengage Learning.

Mulyadi. (2015). Akuntansi Biaya, Edisi5. Yogyakarta: Sekolah Tinggi Ilmu Manajemen YKPN.

Muspami. (2011). Pengaruh Supervisi Pempinan, Iklim Kerja, dan Motivasi Kerja Terhadap. Komitmen Kerja Karyawan Pangeran' s Beach Hotel Padang. Tesis Padang UNP. 
nurcahyani, D. (2016). Pengaruh Keadilan Organisasional Terhadap Komitmen Organisasi Dengan Jarak Kekuasaan Sebagai Variabel Moderating (Studi Pada Pt. Pln (Persero)Apj Semarang). Dipenogor Of Management .

Priansa. (2016). Perencanaan \& Pengembangan SDM. Bandung: Alfabeta.

Putri, F. K. (2015). Pengaruh Keadilan Organisasional Dan Motivasi Kerja Terhadap Kepuasan Kerja Karyawan Toko Buku Uranus . Jurnal Manajemen Bisnis .

Ricky W., a. M. (2014). Organizational Behavior: Managing People and Organizations. Eleventh Edition. . USE: South Western.

Riduwan. (2014). Metode \& Teknik Penyusunan Proposal Penelitian. Bandung : Alfabeta.

Rivai, V. (2014). Manajemen Sumber Daya Manusia untuk Perusahaan, Edisi Ke

6. Depok: PT. Raja Grafindo Persada,.

Robbins. (2017). Human Resource Manajemen. Jakarta: PT. Raja Grafindo.

Sedamaryanti. (2016). Manajemen Sumber Daya Manusia Reformasi Birokrasi Dan Manajemen Pegawai Negeri Sipil. Bandung: PT. Refika Aditama.

Siregar, S. (2014). Metode penelitian kuantitatif dilengkapi denganperbandingan perhitungan manual dan SPSS. Jakarta: Kencana.

Steers, P. d. (2014). Organizational Commitment, Job Satisfaction and Turnover Among Psychiatric Technicians. Journal Of Management Psychology .

Stephen, R. (2014). Perilaku Organisasi. Jakarta: Salemba Empat.

Sugiyono. (2014). Metode Penelitian Pendidikan Pendekatan Kuantitatif, Kualitatif, dan $R \& D$. Bandung: Alfabeta.

Sukidjan. (2018). ManjaemenSumberDayaManusia. Jakarta : Bumi Aksara.

Sunyoto, D. (2012). Manajemen Sumber Daya Manusia. Jakarta: PT Buku Seru.

Sutrisno, E. (2014). Manajemen Sumber Daya Manusia. Cetak Ke Enam. Jakarta: Pranada Media Group.

Suwardi. (2014). Pengaruh Motivasi Kerja, Kepuasan Kerja, Dan Komitmen Organisasional Terhadap Kinerja Pegawai. jurnal Manajemen .

Tamara, G. M. (2016). Pengantar Manajemen. Bandung: Alfabeta.

Udayani, K. A. (2016). Pengaruh Keadilan Organisasi, Budaya Organisasi, Dan Pemberdayaan Karyawan Terhadap Komitmen Organisasional Karyawan Lpd Desa Adat Jimbaran. Jurnal Fakultas Ekonomi dan Bisnis .

Umar, H. (2014). Metode Penelitian Untuk Skripsi dan Tesis Bisnis. Edisi-2. Cetakan ke-13. Jakarta: Rajawali Pers.

Wibowo. (2016). Manajemen Kinerja, Edisi Kelima,. Jakarta: T.Rajagrafindo Persada.

Wirawan. (2014). Kepemimpinan, Teori, Psikologi, Perilaku Organisasi, Aplikasi danPenelitian:Contoh Aplikasi untuk Kepemimpinan Wanita, Organisasi Bisnis,Pendidikan dan Militer. Jakarta: Raja Grafindo Persada.

Yukl, W. \&. (2012). Perilaku Organisasi dan Psikologi Personalia, . Jakarta: Rineka.

Yunita, I. I. (2018). Pengaruh Keadilan Organisasional, Kepercayaan, Dan Motivasi Kerja Terhadap Kepuasan Kerja Karyawan Di Pt. Telkom Tbk, Surakarta . Jurnal Manajemen Bisnis . 